\title{
K NAROZENINÁM DOCENTKY ZUZANY JETTMAROVÉ
}

\author{
VANDA OBDRŽÁLKOVÁ
}

V uplynulém roce oslavila životní jubileum doc. PhDr. Zuzana Jettmarová, MSc., Ph.D., jedna z nejvýraznějších osobností současné české translatologie a dlouholetá pedagožka Filozofické fakulty Univerzity Karlovy.

Zuzana Jettmarová se narodila 18. ř́jina roku 1952 v Praze, v roce 1976 absolvovala obor překladatelství a tlumočnictví na FF UK, v roce 2010 získala titul Ph.D. v oboru translatologie a na konci roku 2017 se úspěšně habilitovala. Její akademická dráha je úzce spjatá $s$ Ústavem translatologie (dřive katedrou překladatelství a tlumočnictví), kam nastoupila jako odborná asistentka $\mathrm{v}$ roce 1981 a kde od té doby vede přednášky a odborné semináře zaměřené na obecně translatologické, lingvistické i metodologické disciplíny. Řada $\mathrm{z}$ těchto předmětů patří $\mathrm{k}$ základu společnému pro všechny jazyky vyučované v ÚTRL, takže se s ní během studia setká každý student kteréhokoli z překladatelských a tlumočnických studijních programů.

V letech 1991 až 2006 zastávala pozici ředitelky ÚTRL, který se pod jejím vedením stal uznávanou a uchazeči vyhledávanou institucí. V souvislosti s transformací katedry překladatelství a tlumočnictví zásadním způsobem přispěla $\mathrm{k}$ vytvoření základní koncepce studijního programu translatologie, který v sobě slučuje jak praktickou př́pravu budoucích překladatelů a tlumočníků, tak teoretické vzdělání v poměrně širokém spektru disciplín, jež představuje základ pro další vědecké a akademické působení absolventů oboru. V období po roce 1989 se zasadila o navazování spolupráce se zahraničními organizacemi a institucemi a vybudovala z ÚTRL pracoviště, které má své pevné místo na mezinárodní scéně. Jako př́klad uved’me členství v organizaci European Society of Translation Studies (EST), kde v letech 1995-2001 působila jako členka výkonné rady a později jako místopředsedkyně, dále členství v organizacích CIUTI a FIT. K internacionalizaci celé fakulty přispívala také jako koordinátorka programu Tempus a Socrates Erasmus a jako referentka pro studium cizinců na FF UK.

V průběhu celé své akademické dráhy se pravidelně účastní domácích i zahraničních konferencí, často v roli hlavního řečníka nebo člena organizačního výboru. Je členkou redakčních rad v odborných nakladatelstvích (např. John Benjamins Publishing) a časopisech (např. Across Languages and Cultures a další). Významná byla její dlouholetá spolupráce s Centrem pro výzkum překladu, komunikace a kultury Katolické univerzity v Lovani, kde opakovaně vystoupila jako hostující profesorka. Završením této spolupráce byly přednášky prof. Lamberta v Praze a stipendijní pobyt několika doktorandů oboru translatologie na letní škole CETRA v italském letovisku Misano Adriatico. 
Coby ředitelka ÚTRL rovněž přispěla k úspěšné rekonstrukci Šporkova paláce realizované v letech 1998-1999, díky které ústav získal krásné a moderně vybavené sídlo budící obdiv návštěvníků z tuzemska i ze zahraničí.

Ve svém úsilí o rozvoj oboru a rozšiřování mezinárodní spolupráce Z. Jettmarová pokračuje dodnes jako garantka a jedna ze stěžejních vyučujících anglického oddělení, členka oborové rady a školitelka řady diplomantů a doktorandů. Ve spolupráci s prof. Janou Královou připravila akreditaci doktorského studijního programu Translation Studies $\mathrm{v}$ angličtině, ve kterém $\mathrm{v}$ současnosti studují tři studenti, $\mathrm{z}$ toho jeden pod jejím vedením. Prostřednictvím předmětu Metody výzkumné práce dohlíží na kvalitu všech diplomových prací zadávaných na ÚTRL. Zapojuje se také do veřejné debaty o tématech souvisejících s překladem, ke kterým zpracovává odborná stanoviska.

Výzkumná a publikační činnost Z. Jettmarové se odvíjí od tří základních vzájemně propojených tematických os. Její páteřní část představuje studium a analýza československých a zahraničních teoretických translatologických východisek a historiografická interpretace českého strukturalismu v celosvětovém kontextu. Tento směr bádání Z. Jettmarové je úzce spojen se snahou upozornit na souvislosti a vztahy mezi českou strukturalistickou tradicí a zahraničními translatologickými směry a školami. Vyústěním tohoto úsilí bylo mimo jiné vydání anglicky psané kolektivní monografie Tradition versus Modernity (2008), jejímž cílem bylo připomenout českému i zahraničnímu publiku základní koncepce Pražské školy. Z. Jettmarová je jednou z editorek publikace a přispěla do ní úvodním přehledovým článkem s příznačným názvem Czech and Slovak Translation Theories: the Lesser-known Tradition (České a slovenské teorie překladu: ménè známá tradice).

Zásadním počinem souvisejícím se zpřístupňováním české translatologie světu je anglický překlad Umění překladu (The Art of Translation, 2011, překl. Patrick Corness), jedné ze stěžejních prací českého teoretika překladu Jiř́ho Levého, který doc. Jettmarová iniciovala a podílela se na něm jako editorka (včetně adaptace výchozího textu pro zahraniční publikum) a autorka kritického úvodu. Za připomenutí stojí rovněž zpracování rozsáhlé české a slovenské translatologické bibliografie od roku 1913 do roku 2003.

V devadesátých letech se zaměřila především na empirický výzkum překladu reklamy a propagačních textů $\mathrm{v}$ postkomunistických zemích. I v tomto prrípadě uplatnila $\mathrm{v}$ zásadě strukturalistická metodologická východiska. Její studie mapující vývoj převodu reklamního žánru v období 1990-2004 předkládají multidisciplinární a mnohovrstevnatý pohled na soubor faktorů ovlivňujících dobovou normu, včetně postojů zadavatelů a př́ijemců, na pozadí rychle se vyvíjejícího historického a společenského kontextu. Jako samostatné podtéma zpracovala koncept překladovosti, který do translatologie zavedl J. Levý a dále ho rozpracoval A. Popovič. Z. Jettmarová tento fenomén zasazuje do širšího rámce jako součást obecnějšího uvažování o cizosti v překladu a empiricky zkoumá, jakým způsobem se odráží ve vývoji reklamního žánru.

Statě a články věnované převážně výše uvedeným tématům publikovala $\mathrm{v}$ řadě tuzemských a zahraničních časopisů (např. Target, Linguistica Pragensia, Translatologica Pragensia), sborníků a monografií. Nejzásadnější výsledky její výzkumné práce jsou shrnuty v monografii Mozaiky prekladu (2016). Významným publikačním př́spěvkem $\mathrm{z}$ poslední doby je kapitola The concept of translation in Slavic cultures (Pojem přreklad ve 
slovanských kulturách) v mezinárodní encyklopedické publikaci World atlas of Translation, která vyjde v roce 2018.

$\mathrm{Na}$ závěr si dovolím poněkud osobněǰsí pohled na oslavenkyni, jíž je tento příspěvek věnován. Není tajemstvím, že mezi studenty je doc. Jettmarová považována za osobu respektovanou, značně náročnou a v lecčems neústupnou. $Z$ vlastní zkušenosti ale mohu říct, že zmíněná náročnost nikdy nespočívala $\mathrm{v}$ samoúčelném lpění na nepodstatných detailech. Ze všech zkoušek a konzultací jsem bez ohledu na výsledek odcházela s pocitem, že jsme si docela prátelsky popovídaly a já měla možnost probírané téma pochopit do větší hloubky. Dnes Zuzanu Jettmarovou vnímám jako zkušenou kolegyni s osobitým smyslem pro humor a neuvěřitelným přehledem o aktuálním dění v české i světové translatologii, vždy ochotnou poradit odbornou literaturu k jakémukoli tématu. Občas přes dveře pracovny zaslechnu útržky jejích rozhovorů se současnými studenty a vždy znovu obdivuji, s jakou pečlivostí a pozorností se každému z nich věnuje. Právě díky obětavosti a osobnímu nasazení, které je motivováno opravdovým zájmem o obor a jeho rozvoj, je doc. Jettmarová nedocenitelnou oporou pro Ústav translatologie i celou fakultu.

Do dalších let přeji paní docentce za celý pedagogický kolektiv Ústavu translatologie především pevné zdraví, neutuchající tvůrčí energii, vnímavé a inspirativní studenty a kolegy, mnoho dalších odborných úspěchů a hodně radosti z pedagogické práce i v osobním životě.

\section{VYBRANÁ BIBLIOGRAFIE}

Jettmarová, Zuzana (2011) 'Editor's introduction to the English edition', in Jiří Levý, The Art of Translation (Umění prekladu. Praha, 1983). Translated by Patrick Corness, Edited with a critical foreword by Zuzana Jettmarová. Amsterdam/Philadelphia: John Benjamins.

Jettmarová, Zuzana (2016) Mozaiky prěekladu. Translation Mosaics: K devadesátému výročí narození Jiřího Levého. Praha: Studia Philologica Pragensia. Karolinum Press.

Jettmarová, Zuzana (v tisku 2017, vyjde 2018) ‘The concept of translation in Slavic cultures', in Yves Gambier and Ubaldo Stecconi (eds.) World atlas of translation, Amsterdam: John Benjamins.

Králová-Kullová, Jana a Zuzana Jettmarová (2008) Tradition versus modernity: from the classic period of the Prague School to translation studies at the beginning of the 21st century. Praha: Univerzita Karlova v Praze, Filozofická fakulta, Opera Facultatis philosophicae Universitatis Carolinae Pragensis. 